\title{
Nogle bemærkninger vedrørende en samlet udgave af Grundtvigs dagbøger
}

(Foredrag ved Grundtvig-Selskabets årsmøde i Århus den 2. december 1976)

\author{
Af Gustav Albeck
}

Det er en kendt sag, at Grundtvig ikke hører til vor litteraturs store memoireskribenter. Han har ikke skabt et sidestykke til Oehlenschlägers Erindringer, eller Hauchs og Ingemanns memoireværker - for slet ikke at tale om Andersens voluminøse selvbiografier. $\mathrm{Og}$ dog yndede han at betragte sit liv retrospektivt og meddelte påfaldende ofte stumper af sin livshistorie, tit i sammenhænge hvor disse retrospektive fragmenter kunne synes lidt umotiverede. Af sådanne større fragmenter kunne Høirup og Steen Johansen i sin tid forme en slags helhed. Men værket, hvori dette sammenbragte hele fremkom, hed karakteristisk nok "Grundtvigs Erindringer og Erindringer om Grundtvig“. For at få et helhedsbillede frem, måtte de to forfattere supplere Grundtvigs egne selvbiografiske erindringer med, hvad folk, som havde kendt ham, havde skrevet om ham.

Når talen er om Grundtvigs dagbøger, frembyder der sig også vanskeligheder ved at skabe et sammenhængende hele. Man kan bedst betegne det relevante materiale som dagbøger og dagbogslignende fragmenter; og materialet omfatter kun kortere perioder af hans liv - først og fremmest hans ungdom: årene 1802-7, nogle spredte notater fra 1813 og 15, og en række korte dagbogsnotitser fra de første to Englandsrejser 1829 og 30 . Herunder findes enkelte notater fra hans senere år - det sidste fra 1855.

En stor del af Grundtvigs såkaldte dagbøger er benyttet i Grundtvig-forskningen - først og fremmest af Rønning i hans store værk - men også af senere forskere som Michelsen, Bugge og Lundgreen-Nielsen. Store partier foreligger trykt i Begtrups Udvalgte Skrifter I, men med mange og store overspringelser. I Koch og Christensens Værker i Udvalg er partierne fra Begtrups udgave 
genoptrykt - og enkelte af Begtrups ikke meddelte afsnit medtaget (desværre ikke uden - til tider ret grove - fejllæsninger). Derimod har Begtrup været meget omhyggelig i sin læsning af de ofte svært læselige papirer.

Jeg har kun opdaget én markant fejltagelse hos Begtrup. Det er i hans gengivelse af den såkaldte omarbejdede dagbog fra 1802 (omarbejdelsen er fra 1804), hvor Grundtvig skriver om moderens kamp for at lære den 4-årige N. F. S. Grundtvig at læse.

Det hedder hos Begtrup: „Hvad der foregik til hans $4^{\text {de }}$ Aar derom veed Frederik selv intet. Ventelig har han som andre faaet Riis og Sukkergodt, dog næppe i Flæng, om han ellers kjender sin Moder ret. - Bemeldte Moder havde den gammeldags Sædvane selv at lære sine Børn at læse ...“. Der står ikke bemeldte Moder, men bemeldte Madam. Måske har Grundtvig haft Wessels digt „Den bekymrede Moder“ i tankerne. Det hedder heri bl. a.: „Madame eller Moer,/ Forskiellen er ei stor.." Jeg har en mistanke om, at Begtrup meget vel har set, at der stod Madam, men har pyntet på sønnens respektløse betegnelse. Jeg bygger denne antagelse på den kendsgerning, at Begtrup adskillige steder udelader partier, der stiller Grundtvig $i$ et mindre flatterende lys. Det gælder f. ex. det store opgør med Constance Leth 17. juli 1806:

„- Men nu - dristig traadte Hun hen for Mig, erklærede med de helligste Forsikringer mine Mistanker for ugrundede og rystede Mig med den ligesaa smertelige som grundede Erklæring, at Hun nu fuldkommen indsaa min Kærlighed til hende var forstilt, thi umuligt var det, Jeg kunde elske en Kvinde, Jeg troede nedsunken i Dyriskhedens nederste Sump. - Med Bitterhed og Afsky udmalede Hun Billedet af hvad Hun maatte være, dersom Jeg havde Ret. Jeg maatte - sagde Hun - ej blot være vellystig, men mit hele Liv maatte tillige være den afskyeligste Maske. Jeg behandler min Mand med Kærlighed og Ømhed, hvad maatte Jeg være, dersom Jeg med dette dog flagrede fra Ens i en Andens Favn? Hvad De tænker, men ej vil sige: en offentlig Hore.“

Udeladelsen kan skyldes hensyn til Constance Leths efterkommere på Egeløkke - men også en lidt skræmt fornemmelse af, at scenen gik lovlig tæt på forholdet mellem Grundtvig og Constance. Men jeg skal nævne en anden udeladelse, som tydeligt nok er foretaget for at undgå at sætte Grundtvig $i$ et mindre flatterende lys. Det er nogle steder fra Dagbogen Februar 1805, et tidsrum, hvor han opholdt sig ofte og længe hos provst Blicher i Gunslev, og hvor tanken om at forlove sig med datteren Lise tager form. 
Med tilfredshed konstaterer Grundtvig d. 22. februar: „Det synes Mig som L. alt tydeligere viser Mig sin Yndest". I samme notits skriver han: „Om i Øvrigt mit Forhold til hin Elskelige (dvs. Lise) vorder tydeligt dennesinde, ved Jeg ey."

Men d. 3. marts dukker en ny ung kvinde op i dagbogen. Hun findes ikke hos Begtrup. Grunden hertil kan næppe være en anden, end at Begtrup har fundet det lidt pinligt, at Grundtvig i dagene efter d. 22. februar har været ved at tabe sit hjerte til en anden pige. Det hedder i dagbogen:

"Intet er mere vexlende end Vexelens Beregner Mennesket -. Den 25 fulgte Ieg min Broder til Idestrup, og fandt der hin før omtalte Gerhardine. ${ }^{1}$ Ieg var samlet med hende til Onsdag Formiddag d: $27^{\text {de }}$ og havde gjerne ønsket at kunne forlænge Samlivet. Ieg ved ikke hvor meget. Hun viste sig efter mit Tykke saa blid imod Mig, at Ieg turde vente, Hun intet vilde have derimod, og hendes Sang hendes Tale, hendes Alt syntes at røbe noget Høyere end det man finder hos den almindelige Pige.

Hvad Under om Hun i Følge slig en Dom søgte hos Mig at fortrænge L. D: (29de) $1^{\text {te }}$ Marts var Ieg et Øyeblik i G:2 hvor Ieg morede Mig saare meget med Pigebørnene, og Alt kom i sin gamle Orden igjen - Provsten bad Mig prædike for sig i Dag hvilket Ieg maatte love skjønt det ey frydede Mig saaledes som sidst - Ieg ved ey selv hvorfor - Nok om det - Ieg vidste Ghde kom næste Dagen - $\left(1^{\text {te }}\right) 2^{\text {den }}$ Marts kom Hun den Hulde og Vi fortsatte Romanen der hvor Vi sidst forlod den -

IV.

Det gjorde Mig halv ondt i Gaar at Ieg skulde til G. ${ }^{2}$ og Ieg (f) bortreyste strax efter Maaltidet uden at det kostede Mig nogen Overvindelse, skjønt Ieg maatte sige Farvel, da min Reyse var bestemt til næste Onsdag. Da Ieg takkede Provsten for al Høflighed, bad Han Mig stedse være en Ven af sig og sit Hus, hvilken Bøn tyktes Mig unødvendig, men dog ey saa overflødig som den for 8 Dage siden vilde været - L. var saare mild ved Afskeden, og denne Mildhed vover Ieg ey at forklare - Ieg red til Nebølle, hvor min Broder var med de Flere, og hvor Vi bleve om Natten.

V.

$\mathrm{Nu}$ er det forbi - I Gaar Formiddag naaede Vi atter Torkilstrup - $\mathrm{G}^{\mathbf{3}}$ : sad om Middagen - som det lod gjerne - ved min Side - Om Aftenen valgte Hun Plads ved Siden af sin Moder saaledes at vore Fødder finge Kommunikasjon, men neppe et Tryk og Gjentryk, saa kom min Broderkone og jog hende op $\mathrm{O}$ hvor Ieg vrededes!

1. Gerhardine må have været omtalt på et af de tabte blade fra dagbogen.

2. G: = Gunslev.

3. G: = Gerhardine. 
I Morges maatte Hun reyse hvilket slet ikke syntes at behage hende. Hun var tankespredt, og ofte dvælede hendes Øye ved Mig som halv sørgende Kunde Ieg nogle Uger være samlet med hende, og Ieg vidste at L: var ligesaa mild, indvortes som udvortes da Ieg tog Afsked, da troer Ieg...“.

Denne lille romance er uomtalt hos Begtrup - men trykt af Koch og Christensen, i Værker i Udvalg I, s. 57, hvor det hedder: „Hvem denne Gerhardine er, kan ikke oplyses“.

Det kan imidlertid oplyses, hvem Gerhardine var, nemlig en 18-årig datter af justitsråd Chr. Hincheldey, som bl. a. ejede Ourupgaard i Idestrup Sogn. Justitsråden døde 1793, og Gerhardine flyttede i 1809 med sin mor til København, hvor hun døde ugift i Gentofte Sogn d. 30. 1. 1850.

Der skal ikke her lægges op til en romantisk myte om den unge, dejlige herregårdsdatter, der nogle dage i 1805 var genstand for en ung, vordende digters beundrende tilbedelse, en dansk Tatjana, som blev svigtet af sin Eugen Onegin, og som henlevede resten af sit liv i ugift stand. Men det er ikke uden interesse at vide, at Grundtvig allerede som ganske ung synes at have haft en speciel evne til at betages af herregårdsfrøkner eller -fruer, i hvert fald kvinder af stand og dannelse.

Hermed stemmer de betragtninger, som han d. 8. september 1806 gør i sin dagbog om muligheden for at fa kraft til at kæmpe imod den "ulyksalige Ild“, der rasede $i$ hans barm (forelskelsen $i$ Constance Leth), dersom han traf „en Pige Jeg uden at elske, dog kunde slutte mig til med Velbehag". Det hedder udtrykkelig, at hun "maatte med tækkelig Udvortes forbinde Godhed og Aandsdannelse, om ikke i højere saa dog ej heller i stort ringere Grad end min Herskerinde -“ (U.S.I, pag. 99).

Til dagbogsmaterialet hører også den såkaldte Lektions- og Karakterbog for Karl Steensen de Leth, som i forskningen har været benyttet af både Rønning og Michelsen - og af mig i mit foredrag om Huslæreren på Egeløkke, Grundtvig-Studier 1959, hvor jeg aftrykte store partier af manuskriptet, der på forskellig vis supplerer adskillige ting i den samtidig førte egentlige dagbog. Ved udarbejdelsen af mit manuskript til den samlede dagbogsudgave har jeg - med skam at melde - måttet konstatere, at jeg enkelte steder har læst fejl, hvad jeg nu får lejlighed til at bøde på. En ringe trøst er det for mig at have konstateret, at den udgi- 
velse af hele Lektions- og Karakterbogen, der er trykt i Bugges "Grundtvigs Skoleverden“, lader en del tilbage at ønske med hensyn til korrekt læsning og gengivelse. Når jeg i denne forbindelse nævner ordet „trøst“, er det ud fra den tanke, at når en så dygtig og samvittighedsfuld forsker som Bugge (der tilmed har haft yderst kompetente hjælpere med korrekturen) kan have ret så mange fejllæsninger, hænger det sammen med de store vanskeligheder, der er forbundet med at råde Grundtvigs runer. Det er en kendsgerning, som nok kan fylde den, der har påtaget sig opgaven at besørge noget i retning af en mønstergyldig edition - med frygt og bæven. I denne forbindelse vil jeg gerne sige, at der bag mit arbejde på udgivelsen af Grundtvigs Dagbøger - som Det Danske Sprog- og Litteraturselskab har betroet mig - ligger ønsket om at levere, hvad der kunne blive de første to bind i den store, videnskabelige udgave af Grundtvigs samlede skrifter, som vi, der har været med i Grundtvig-Selskabet fra dets start, ofte har fablet om - og som vi næppe får at se, men som bør komme.

Så spredt og fragmentarisk som Grundtvigs dagbogsmateriale end er, fortjener det at fremkomme som en helhed - og uforkortet. Først samlet i een udgave vil det komme til sin ret, og først anskuet i sin helhed tegner det et sandt billede af Grundtvig i hans ungdoms- og brydningsår - og føjer nye træk til vor viden om mennesket og skribenten N. F. S. Grundtvig.

Det er ikke usædvanligt at unge mennesker fører dagbog - ej heller at de efter kortere eller længere dagbogsskriveri hører op dermed. I så henseende danner Grundtvig ingen undtagelse. Om han i sin skoletid har ført dagbog, ved vi ikke. I så fald må den være gået tabt. Men han nævner ikke noget derom, og jeg er mest tilbøjelig til at tro, at han var en novice $\mathrm{i}$ dagbogskriveri, da han d. 28. november 1802 begyndte at skrive på den første af de bevarede dagbøger.

Han skrev på forsiden en strofe, der klart dokumenterer, at det er hans agt at føre en egentlig dagbog - altså med notitser dag for dag:

Hvad er en Dag? Et Øieblik

Vi neppe Tid at skue fik

Og dog af lutter slige Dage

Vor Levetid bestaar 
Hvo er vel den som fræk tør klage

Han ikke nok af Dage faaer

Lad ham Dem sammen regne!

Og ved enhver antegne

Hvad han paa den har gjort

Da skal han see hvis Skyld det er

Hans Levetid var kort -

Det er jo lidt af et programskrift - en forpligten sig til hver dag at aflægge regnskab for, "hvad han paa den har gjort". En forpligtelse Grundtvig aldeles ikke kunne opfylde.

Den citerede strofe er ikke bevaret blandt fragmenterne af ms. til den oprindelige dagbog fra 1802. Vi kender den kun fra den såkaldte omarbejdede dagbog fra 1802 (som han udarbejdede 1804). Men vi har andetsteds i dagbogen hans ord for, at strofen er fra 1802.

De bevarede fragmenter af 1802-dagbogen viser, at Grundtvig omend med besvær - har søgt at leve op til sit forsæt om at gøre regnskab for hver enkelt dag i sit liv. Men allerede her kommer et karakteristisk træk ved hans dagbogsskriveri til syne: trangen til at indføje kortere eller længere tilbageblik i teksten. Det er således klart, at han i 1802 har påbegyndt sine dagbogsoptegnelser med et længere retrospektivt afsnit, omhandlende hans liv fra barndommen i Udby og til november 1802 . Vi har ganske vist kun bevaret nogle få sider af dette afsnit, omhandlende provinsstudentens trængsler ved mødet med det toneangivende københavnske borgerskab i morbroderen, professor F. L. Bangs hjem. Vi genfinder skildringer - $\mathrm{i}$ en litterært bearbejdet, noget arrogant og ironisk stil - i den omarbejdede dagbog fra 1804, hvor den er en del af en samlet fremstilling af hans liv fra fødslen og til november 1802. Det går endda mere præcist at sige: til den 28. november 1802.

Denne dato satte Grundtvig - hvad den omarbejdede dagbog røber - under den ovenfor citerede "program"-strofe. Og det var ikke en tilfældig dato. Samme dag havde han indleveret manuskriptet til sin første komedie "Skoleholderne“ til Det kgl. Teater. Hans liv som professionel skribent, digter, tog sin begyndelse den dag. I denne kendsgerning finder man hans bevæggrund til at påbegynde sit dagbogsskriveri. Men først måtte han gøre rede for skribenten N. F. S. Grundtvigs vita ante acta. Derfor indeholder afsnittet fyldige redegørelser for hans ungdommelige, længe mis- 
lykkede, forsøg på digterisk udfoldelse. Det er den vordende skjalds første litterære testamente.

At drømmen om succes som komedieforfatter hastigt brast, fremgår af de følgende sider af den omarbejdede dagbog. Heri meddeles en afskrift af et brev fra Det kgl. Teaters direktion, som underretter ham om, at teatret ikke kan finde anledning til at spille hans komedie. I fortsættelse heraf citerer Grundtvig, hvad han d. 9. december 1802 skrev i sin (originale) dagbog:

„Paa det Sted i Gs Dagbog, hvor dette er anført - nemlig $9^{\text {de }}$ Desbr - finder Ieg følgende „At Ieg efter denne Promemorias Erholdelse, ikke mere skriver Komedier men følger dette Vink, er begribeligt da det er mig Borgen for Jeg fattes Talent til at arbeide for Skuepladsen ...

Nok er det. Ieg har hørt Røsten „Sutor ne ultra crepidam! Jeg vil kaste Pennen og begrave mig i Theologi“" “.

I slutningen af den omarbejdede dagbog, der i særlig grad omhandler hans digteriske ambitioner i tiden december 1802 til maj 1804, kommenterer han sine bitre ord efter skuffelsen:

„At G: virkelig skrev, hvad han tænkte, kan gjerne være, men at han $\mathrm{i}$ ingen Henseende udførte sin desperate Beslutning veed Ieg - “.

Den omarbejdede dagbog blev i realiteten ikke nogen dagbog. Hvad der interesserede Grundtvig i 1804 var blot at give en levnedsskildring (ført ajour til 30. maj 1804) skrevet $\mathbf{i}$ en litterær (arrogant og selvironisk) stil. Noget kunne tyde på, at han havde en offentliggørelse i tankerne. Derfor distancerede han sig også fra forlægget ved at ombytte alle Ieg'erne og Mig'erne med han eller Grundtvig. (Helt lykkedes denne udskiftning fra 1. til 3. person dog ikke). - Og derfor medtog han ikke de egentlige dagbogsnotitser fra dagbogen 1802. Kun den bitre kommentar i anledningen af afslaget fra Det kgl. Teater er en autentisk dagbogsnotits fra originalen.

De bevarede - ikke-benyttede - fragmenter rummer dels korte bemærkninger om hans daglige færden, dels kommentarer til hans læsning-samt hans indtryk fra og korte bemærkninger til Steffens' forelæsninger. Alle hans bemærkninger til hans læsning - på een undtagelse nær - har stået i partier af den oprindelige dagbog - under året 1803, vel at mærke på ark og sider, som nu er gået tabt. 
Når vi alligevel kender nogle af dem, skyldes det, at han i 1805 besluttede sig til at indføre excerpter af og kommentarer til sin læsning i en særlig Udtogsbog. Også her gik han retrospektivt til værks. De første sider af Udtogsbogen indeholder citater af hans excerpter og kommentarer fra 1803 - vel at mærke forsynet med nye kommentarer, der så at sige alle har til formål at vise, at han i 1805 har et andet og „højere“ syn på digtningen og tilværelsen end to år forinden.

De bevarede dele af den originale dagbog fra 1802-3 indeholder en hel del vidnesbyrd om, at Grundtvig gerne ville leve op til sit forsæt om "ved enhver (dag at) antegne / Hvad han paa den har giort". Det er ganske dagligdags notitser. Karakteristik af mennesker, han møder, findes så godt som aldrig, og optegnelser om natur- og synsindtryk slet ikke; for ikke at tale om bemærkninger om vejr og vind. Der er langt fra dagbogsskribenten N.F.S. Grundtvig til kollega H. C. Andersen. Derimod beretter han - som alt nævnt - gerne om intellektuelle oplevelser, herunder sine indtryk fra Steffens' forelæsninger i december 1802. Det første bevarede dagbogsfragment fra december 1802 omhandler menneskets erkendelse af, at „denne Evne til at giøre Reflexioner over Aarsag og Virkning er det eneste hvorved Mennesket hæver sig over Dyret". Et og andet kunne tyde på, at han her kommenterer en ytring af Steffens, hvis forelæsninger han, i den udstrækning han kunne følge tankegangen, påhørte med kritisk opmærksomhed. Han kommenterer med følgende bemærkning: „Hvis saa er da komme mange Mennesker ogsaa fra denne Side betragtet til at staae i Klasse med Dyrene - ", og bruger som bevis, at mange mennesker spiller i lotteriet: „hvor ofte tabte ikke et Menneske 99 Gange og satte dog den hundrede Gang ind i fuld Forventning om at vinde skiønt han vidste der var 85 Nitter og -5 Træffere".

Han afslutter refleksionen med nogle ord om begrebet Kraft, idet han hævder, at „Vi vide ikke ... Forskellen paa et Legems vilkaarlige og uvilkaarlige Bevægelser - ".

Her slutter refleksionen, og en hverdagsnotits følger:

„Ieg er for kold om Hænderne til at Ieg skulde have Lyst til at skrive mere herom. Efter Kollegiummets Anhørelse gik Ieg hiem - spiste lidt gik ud igien kom hiem Kl. $8^{1 / 4}$ læste et Kapitel Ef. $=1^{1 / 2}$ Ark nok et Kap. $=1$ Ark ialt 3 $\frac{1000}{2000}$ Ark. Derpaa gik Ieg i Seng Kl. 12 og læste 22/4 Ark Moral. Den Dags Udgifter 4 sk til Svamp -“. 
De følgende dagbogsoptegnelser er på lignende måde blandinger af mere eller mindre indgående kommentarer til Steffens' forelæsninger og rent dagligdags hændelser. Den 14. december refererer og kommenterer han docentens meninger om Hume og standser brat op med ordene: „Ieg gider ikke skrive meere -“.

Den følgende dag er han helt i dovenskabens vold:

„15 tende Bestilte Ieg slet intet Formiddag og Eftermiddag var paa Conversatorium hvor intet mærkværdigt forefaldt modtog 2 Øe og læste 1 Ark Moral -“

Noget lignende gælder de følgende dage.

Den 19. hedder det således: „Bestilte intet hele Dagen var om Aftenen hos Dørup tilsatte 1 Mark 8 sk. Gav 4 sk ud til Svamp gik hjem og sov".

I Dørups konditori var Grundtvig i det hele taget en flittig gæst og drak chokolade. Han er der også den 21. december - hvorefter han går hjem for at pakke sin vadsæk. Han skal den følgende dag begive sig på vej hjem til Jul i Udby. Rejsen skildres med nøjagtige opgivelser af udgifter til mad og logi i dagene 22.-23., da han kl. 41/2 om eftermiddagen når faderens præstegård.

Optegnelserne fra juleugen er af lignende karakter og indhold. Af større interesse er hans skildring af sine oplevelser på prædikestolen i Udby og Ørslev, hvor han prædiker 2. juledag: „2 gange maatte (jeg) snyde min Næse og spytte nogle gange for at recreere mig“, en tilståelse, der kunne tyde på, at han havde lært sig visse taletekniske kneb ved læsningen af Christian Bastholm: „Den gejstlige Talekonst“, men ikke tilegnet sig den magt over "gebærderne", som Bastholm ville bibringe sine læsere.

Først i januar 1803 kommer der liv over beretningen. Det er, da han kommer til Torkilstrup og Gunslev og træffer provst Blichers dejlige døtre og specielt betages af den ældste, Marie. Det må i det hele taget siges, at det i ganske særlig grad er inspiration fra det svage køn, der bringer spændinger i hans dagbog. Det gælder som man vil vide - i fortrinlig grad dagbogsoptegnelserne fra Egeløkke.

Men det, der giver Grundtvigs dagbøger deres særpræg og største værd, er - som allerede omtalt - optegnelserne om hans læsning og de kommentarer og refleksioner, læsningen fremkalder. Ovenfor er nævnt bemærkningerne, der er foranlediget af hans 
tilstedeværelse ved Steffens' kollegier. Men det første vidnesbyrd om påvirkning af lasning stammer fra 21. december 1802, den aften han pakker vadsækken inden afrejsen til Udby. Han har fået

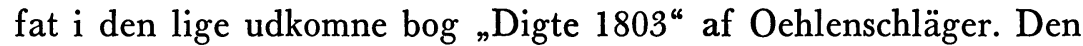
må han straks læse. Han har sine indvendinger mod nogle af digtenes sproglige form, men at bogen har optaget ham, fremgår af slutningen på notitsen: „Ieg lagde mig til at sove Kl. 5 ..." (om morgenen). Af den følgende notits fremgår, at han skulle op kl. 8!

Der findes ikke mange slige notitser $\mathrm{i}$ de bevarede optegnelser fra 1803. Men en række dagbogsnotitser fra 1. februar til 8. september (hans fødselsdag) er gået tabt. Han var i dette tidsrum optaget af sin eksamenslæsning, og selv om han ind imellem fik tid til at spille amatørteater (oven i købet i sin egen komedie Brevet), har han næppe givet sig tid til megen anden læsning end teologien - og formentlig kun i begrænset omfang ført dagbog. Eksamen fandt sted i oktober 1803 og fik et ret dramatisk forløb. Det fremgår ikke direkte af dagbogen, som stopper d. 28. september og først føres videre d. 8. november. Men 14. maj 1804 sætter han sig ned for at udfylde tomrummet fra sidst i september til 8. november 1804 med et Appendix, der får titlen Min Attestateses sandfardige Historie. Redegørelsen har for så vidt dagbogskarakter, som den bringer nøjagtige datoangivelser, men er en retrospektiv konstruktion - af lignende art som den omarbejdede dagbog 1802. Men ligesom denne hører den hjemme blandt Grundtvigs dagbøger.

Fra det øjeblik cand. theol. N. F. S. Grundtvig i november 1803 kommer hjem til Udby - lettet over sin eksamens mirakuløst heldige forløb - begynder dagbogen at vrimle med vidnesbyrd om hans flittige brug af bøger i faderens bibliotek - og læsning af nyudkomne skrifter.

15. november 1803 begynder han at læse Gebhardis Danmarkshistorie - samtidig med at han kaster sig over Krafts oversættelse af Addisons Spectator.

Dagen efter har han fat i Rahbeks oversættelse af Eberhardts Haandbog i Estetiken. Han er inde på tanken om at genoptage sin digteriske virksomhed - både som dramatiker og forfatter af historiske fortællinger. 
- Der er desværre en lakune i dagbogsmaterialet fra 3. december 1803 til 19. februar 1804. I dette tidsrum er han langt inde i sit Holberg-Studium (det, som Bugge så interessant har gjort rede for i Guldalderstudier) ${ }^{4}$ og allerede dukker i omtalen af Rostgaard contra Holberg den unge Grundtvigs uvilje mod adelige og andre potentater op, hans demokratiske og antiaristokratiske, ja skarpt radikale holdning, som dagbogen fremefter viser talrige eksempler på. Mere og mere bruger han dagbogen til excerptbog og til refleksioner over sin læsning.

En såre vigtig oplysning dukker frem under 28. februar 1804: „Sæmunds Edda er oversat af Sandvig 1785“ - det første vidnesbyrd om genvakt interesse for Nordens Mytologi og for norrøn digtning. Side om side med dagbogsberetninger, der kredser om hans kønsdrift og tanker om et muligt ægteskab med Lise Blicher - vrimler det med excerpter og refleksioner over æstetiske, filosofiske, historiske og politiske forhold. Efterhånden tager sådanne optegnelser i den grad overhånd, at egentlige dagbogsnotitser fuldstændig forsvinder. Først 11. juli 1805 - da han sidder på Egeløkke, kommer han - som ovenfor nævnt - i tanker om, at det nok var bedst at indføre excerpter af læsningen i en særlig bog: „min Dagbog forekom Mig det passeligste Sted for slige Optegnelser“, skriver han i en fortale. "Men nu finder Ieg, at disse tvende ey uden begges ubodelige Skade kunne forenes".

Alligevel smuttede udprægede dagbogsnotitser ind $\mathrm{i}$ hans udtogsbøger - og vidnesbyrd om hans læsning ind i dagbøgerne.

Ligeledes kom - som ovenfor omtalt - den Lektions- og Karakterbog, som han i 1806 førte over sin undervisning af Karl Steensen de Leth, til at indeholde adskillige notater, der supplerer hans egentlige dagbog fra samme tid.

Der kan forøvrigt opstå tvivl om, hvorvidt nogle af de bevarede manuskripter fra Egeløkke-tiden skal betragtes som forarbejder til litterære arbejder eller - som dagbogsstof. Det gælder f. eks. fasc. 264.1, der ganske sikkert er et forarbejde til Nordens Mythologi, og hvori han pludselig - med angivelse af datoen 12. juni-skriver:

4. Guldalderstudier, festskrift til Gustav Albeck, 1966, p. 1-9. 
"Jeg troer min Død nær, og derfor skynder jeg mig her at give Resultaterne af min Granskning da de maaske kunne benyttes af Andre. - Lever jeg til i Morgen skal jeg udvikle alt dette nøjere...

12. Juni 1807.

Skougaard skal have alle mine Optegnelser om Edda, hvis jeg døer" -

Det er klart, at disse linjer skal med i dagbogsudgaven, men det samlede manuskript hører - i en kommende samlet udgave hjemme $\mathrm{i}$ et bind med forarbejderne til Nordens Mythologi 1808.

Til de her meddelte spredte og langt fra udtømmende bemærkninger om Grundtvigs dagbøger, smagsprøver fra en kommende udgave, skal yderligere føjes et par detaljer vedrørende Grundtvigs excerpter af Eysteinn Ásgrimssons store, norrøne Mariakvad Lilja. Grundtvig stødte på digtet under læsningen af Finni Johannæi Historia Ecclesiastica Islandiæ (II, pag. 398 ff). Det var af dette værk, han udledte sine første kundskaber vedrørende vestnordiske sprog - fordi de islandske tekster var oversat til latin - et sprog Grundtvig beherskede. Optegnelserne stammer fra midten af juni 1804 - på et tidspunkt, da Grundtvig var en teologisk kandidat „uden ånd og tro" (som han selv har betegnet sig) - i hvert fald kølig rationalistisk i sin livsholdning - og på et tidspunkt, da han endnu ikke havde aflagt bevis på sine store digteriske evner. Det er derfor såre bemærkelsesværdigt, at han er stærkt betaget af Eysteins kvad, ja at hans oversættelse af en enkelt strofe viser, at kvadet forløser både kristne følelser og digteriske evner i ham. Jeg tænker på Liljas strofe 61, om hvilken han i dagbogen skriver: „Et meget poetisk Vers - synes mig“.

Strofen lyder i oversættelse (Den norsk-islandske Skjaldedigtning II B, pag. 406):

„Alle hælvedes jærnporte ryster; mørket undrer sig over, at lysets magt er stærkere; djævlene løber og agter at fly, og sagde, at nu var det uhørte ting der skete; rædslen fløj omkring i dødens bygder; de hellige mænd, hvem lænkerne omspændte, måtte djævlen give slip på, lamslået og såret, da magten krævede det."

Mens Grundtvig i sin oversættelse af andre strofer fra digtet har tilstræbt en ordret oversættelse, meddeler han en meget fri, rytmisk formet og med poetiske billeder udsmykket fordanskning af strofe 61, hvis otte linjer - i Grundtvigs omdigtning - bliver 
til tre ottelinjede strofer. Det er det eskatologiske perspektiv i Eysteins strofe, der kalder på Grundtvigs visionære og poetiske kræfter. Han skriver over sine 3 strofer ordet Omtrent. Det er en underdrivelse. Hans møde med strofen afføder et selvstændigt digt:

\author{
Raslende aabned sig Helvedes Porte \\ Jernet blev vagt som det voxende Straa \\ Mørket forbauset af lysende Straaler \\ Hylded sig undrende ind i sig sel, \\ Djævlene skjalv ved uventede Syn \\ Angstende kneised de gloende Mure \\ Ilede rundt for ved ukjendte Lys \\ Gjennem en Vraa at berede sig Udgang. \\ Hvinende sused nu Vinden igjennem \\ - Seklers tillukte - nu aabnede Port \\ Skokke af Rædsler med spredede Vinger \\ Hæved ved Luftens paavirkende Kraft \\ Hellige hidtil vansmægtende Mænd \\ Rysted nu af sig betyngende Lænker \\ Som for de Paradis tabendes Synd \\ Alt i Aartusinder skar deres Lemmer. \\ Dødskæmpen hos den bedagede Slange \\ Fnysende skued de Hellige fri \\ Rasende greb han fravristede Kæder \\ Søgte at hævde sin spottede Magt. \\ Truffet af Lynildens hæftige Slag \\ Stod han forknust og hans kraftige Flammer \\ Naade ei hine som jublende fore \\ Løste ved Herrens udskænkede Vælde.
}

Her er klang af barokkens salmetone, den man langt senere fornemmer i Grundtvigs digtning. Det er sandt nok en ung og uøvet digter, der prøver at løfte sin røst - men ingen kan være i tvivl om, at det er en digter.

Dette er blot et af de mange - for offentligheden endnu ukendte - bidrag til belysning af den unge Grundtvig, som dagbogsmaterialet rummer.

Til slut endnu et citat af Grundtvig fra en senere tid og $i$ en helt anden stil. Det er begyndelsen til hans Dagbog 1815. Den lyder således: 
„1. Meer end otte Aar ere nu forledne, siden jeg lod af at optegne daglig, hvad mig tykdes vigtigt af Tanker eller Hændelser, og jeg lod af, fordi Meget, som før havde syndes mig vigtigt, stod nu anderledes for mig, og fordi jeg paa den Tid ved at indtræde paa Skribentbanen fik en anden Hensigt med hvad jeg nedskrev. Jeg anseer det imidlertid for urigtigt, at jeg ei fra den Stund jeg begyndte mit christne offenlige Liv, fra 1811, ei optog min forrige Sædvane, thi mangen ei uvigtig Forhandling, mangen enkelt Bemærkning vilde derved være opbevaret til Brug og Opbyggelse. Vist nok er det saa, at hvad der skal ihukommes, det minder Herren os Selv om paa underfulde Maader, og uden en saadan Mindelse, hverken kan eller maae vi bruge Noget, men aldenstund Gud giver os Leilighed til at giemme hvad vi mene kan være til Hans Tieneste og Ære, da bør vi ei dermed være skiødesløse, at vi ei skulde vorde som de der friste Gud. Forhindres vi alligevel fra at optegne hvad vi tykke vigtigt, da skal vi ei derom videre bekymres, naar det kun er i vort $\mathrm{Hjer-}$ te, at vi vil, og ei forsømme det af Ladhed eller Ligegyldighed; thi Gud haver herudi, som i Alt Sine urandsagelige Raad, for hvilke vi skal have taus Ærbødighed og ei vilde forstaae over det som (ei) er os givet at forstaae. Denne Betragtning trøster mig ogsaa over hvad mig synes at være gaaet forloren $\mathrm{i}$ de sidste Aar, thi megen Skyld troer jeg ei deri at have. Adskilligt er ogsaa optegnet $i$ en Almanak og andensteds, og hvad som ellers skal ihukommes, vil Gud af Naade paaminde mig om, ligesom jeg da har i Sinde, om Han vil, at indrykke det her, som det kommer. - Noget Saadant er vel den Handel ved sidste Dionysii Landemode, som jeg her vil beskrive sandfærdigt og som de Beviser jeg har i Hænde for det Meste bevidne.“

Det lyder altsammen meget løfterigt. Men der blev intet af hans gode forsæt udover et stykke retrospektiv selvbiografi omhandlende hans optræden på Dionysii Landemode i september 1814. Men skildringen blev først nedfældet 1. januar 1815, tre-fire måneder efter den omhandlede episode.

Først i 1829-31 tog han - under Englandsrejserne - på ny fat på at føre dagbog, - men kun i begrænset omfang.

Grundtvig var ikke nogen passioneret dagbogsskribent. Langt snarere yndede han de små historiske tilbageblik på vigtige hændelser i sit liv. Alligevel er hans dagbøger en uundværlig del af hans forfatterskab, hvad den kommende udgave formentlig klart vil dokumentere. 